\title{
The potential of Telenomus remus Nixon (Hymenoptera: Scelinoidae) as Biocontrol Agent for the New Fall Armyworm S. frugiperda (Lepidoptera: Noctuidae) in Indonesia
}

\author{
DOI: 10.18196/pt.2020.116.-69-74
}

\author{
Adha Sari ${ }^{1}$, Damayanti Buchori ${ }^{1}$, Ihsan Nurkomar ${ }^{2^{*}}$ \\ ${ }^{1}$ Department of Plant Protection, Faculty of Agriculture, IPB University. \\ Jl. Kamper, Kampus IPB Dramaga, Bogor, 16683. Indonesia \\ ${ }^{2}$ Department of Agrotechnology, Faculty of Agriculture, Universitas Muhammadiyah Yogyakarta. \\ Jl. Brawijaya, Kasihan, Bantul, Yogyakarta 55183. Indonesia \\ *Corresponding author,email: ihsan.nurkomar@umy.ac.id
}

\begin{abstract}
The fall armyworm Spodoptera frugiperda is an emerging new pest species in several Asian countries including Indonesia. This pest can be a threat to Indonesian agriculture because this pest has been reported to cause many losses in other countries. As a preemptive and ecofriendly control strategy, a research to study the performance of Telenomus remus as potential biocontrol agent of this pest was done in laboratory scale. Research was done by exposing an adult female to 50 eggs of S. frugiperda in a cluster. We also exposed the female parasitoid to another 50 eggs of S. litura in a cluster for comparison since this parasitoid had been reported as S. litura egg parasitoid in Indonesia previously. Results showed that there are no difference in the numbers of parasitized eggs, parasitism rate, survival rates and percent females of T. remus reared from both S. frugiperda and S litura, which implies the effectiveness of T. remus as a candidate for biocontrol agent for S. frugiperda.
\end{abstract}

Keywords: Biological control, Parasitoid, Spodoptera frugiperda, Telenomus remus

\section{ABSTRAK}

Ulat grayak Spodoptera frugiperda merupakan hama baru di beberapa negara Asia termasuk Indonesia. Ulat grayak dapat menjadi ancaman bagi pertanian di Indonesia karena hama ini telah dilaporkan dapat menimbulkan kehilangan hasil dalam jumlah banyak di negara-negara lain. Sebagai tindakan pengendalian preemptive yang bersifat ramah lingkungan, sebuah penelitian dengan tujuan mempelajari kemampuan Telenomus remus sebagai agen hayati potensial bagi S. frugiperda telah dilakukan pada skala laboratorium. Penelitian dilakukan dengan cara memaparkan satu T. remus betina dewasa terhadap 50 telur S. frugiperda. T. remus juga dipaparkan terhadap 50 telur S. litura sebagai perbandingan. S. litura dipilih karena T. remus telah dilaporkan efektif dalam mengendalikan S. litura. Hasil penelitian menunjukkan bahwa jumlah telur yang diparasit, tingkat parasitisme, kemampuan bertahan hidup dan jumlah keturunan betina T. remus yang dihasilkan baik dari inang S. frugiperda maupun S. litura tidak berbeda. Dengan demikian, parasitoid telur T. remus dapat digunakan sebagai agen hayati potensial bagi S. frugiperda.

Kata Kunci: Pengendalian hayati, Parasitoid, Spodoptera frugiperda, Telenomus remus

\section{INTRODUCTION}

Spodoptera spp. (Lepidoptera: Noctuidae) are the Kalimantan island (BBPOPT, 2019). This pest was common pest of Indonesia including Spodoptera litura and S. exigua (Kalshoven, 1981). Spodoptera litura is the most voracious among the genus of Spodopotera which is commonly found in leguminous plants (Tengkano \& Suharsono, 2005) and S. exigua is commonly found in onion and other found attacking corn in a low population in Java (Maharani et al., 2019). In contrast, Trisyono, Suputa, Aryuwandari, Hartaman, and Jumari (2019) reported the $100 \%$ infestation level of S. frugiperda in Lampung.. This pest can also attack another crop 170 plant species (Zhang, Huai, Helen, \& Wang, 2011). In the meantime, Spodoptera frugiperda is a newly reported pest species of Indonesia in 2019. such as soybean, cotton, rice and other grasses, and weeds (Nabity, Zangerl, Berenbaum, \& DeLucia, 2011; Pogue, 2002). S. frugiperda originates from This pest was found around Sumatera, Java, and America (Sparks, 1979) and widespread to Africa in 2016 (Goergen, Kumar, Sankung, Togola, \& 
Tamò, 2016) threatened corn yield loss of 8.3 to 20.6 million tons per annum ((Day et al., 2017). In 2018, this pest was reported from China with a quick distribution rate of up to 17 provinces in a month (Jiang, Liu, \& Zhu, 2019). S. frugiperda was also reported in India, Bangladesh, Thailand, Myanmar, and Sri Lanka in 2018 (CABI, 2019a).

Maharani et al. (2019) stated that the low infestation level of S. frugiperda in Indonesia is followed by the presence of natural enemies such as parasitoid and entomopathogenic pathogens in the field with unclear parasitism rate. The presence of natural enemies in the field is an insight for possible natural control taken in the future. One possibility for controlling S. frugiperda is the use of natural enemies that is egg parasitoid Telenomus remus Nixon (Hymenoptera: Scelionidae) (Kenis et al., 2019).

Telenomus remus is an egg parasitoid of various lepidopteran pest species including genus Spodoptera (CABI, 2019b). Buchori, Herawati, and Sari (2017) reported that the release of T. remus able to suppress $48 \%$ population of S. exigua in potted onion plants. Meanwhile, Satyanarayana, Ballal, and Rao (2005) reported 96\% parasitism rate of S. litura eggs by T. remus. Furthermore, Liao et al. (2019) showed that field parasitism incidence of S. frugiperda by T. remus in the field in China can reach up to $60.19 \%$. Biecological key aspects of parasitoid is an important factor in determining parasitoid performance in controlling a pest in the field (Waage \& Hassell, 1982). However, no study reports the bioecological key aspect of T. remus in S. frugiperda. In this research, we study the performance of T. remus on S. frugiperda and compare it to S. litura under laboratory conditions. This is a preemptive control strategy that can be used for natural and sustainable control of S. frugiperda using parasitoid in the future.

\section{MATERIALS AND METHODS}

Insect mass rearing

Both S. litura and S. frugiperda larvae were collected from a corn field in Dramaga, Bogor, Indonesia. Both larvae were taken to the laboratory for further observation. To avoid cannibalism among the larvae, each larva was reared separately in a divided plastic container. Larvae were fed using baby corn which is replaced every two days. The last instar larvae were transferred to a plastic container $(35 \times 28 \times 7 \mathrm{~cm})$ containing sterilized sand as a media for pupation. The pupae were placed in a cylindrical plastic cage $(\mathrm{d}=15 \mathrm{~cm}, \mathrm{~h}=10 \mathrm{~cm})$ until the emergence of the moth. The moths were reared in the similar cage for pupation. The moths were fed using a $20 \%$ honey solution.

Meanwhile, collected parasitized larvae of S. frugiperda were reared in a $50 \mathrm{ml}$ test tube containing honey droplets as a food source until the emergence of the adult. Two days after emergence, a mated female of $T$. remus was introduced to a petri dish (86 x $13 \mathrm{~mm}$ ) containing S. frugiperda egg cluster. Parasitized S. frugiperda larvae were reared using the same method for rearing unparasitized larvae until the formation of $T$. remus pupae. These new emerging parasitoids were used for the experiment.

\section{The performance of T. remus on S. frugiperda}

The performance of T. remus on S. frugiperda was tested by exposing a mated female to one egg mass consisting of 50 eggs of S. frugiperda for $24 \mathrm{~h}$ in a $250 \mathrm{ml}$ test tube. Honey droplets were provided as an additional food source. After the test, parasitized eggs were reared until the emergence of the new parasitoids by the similar method for rearing the parasitoid. The test was repeated ten times using different females. Parameter tested including the number of parasitized eggs, parasitism rate, number of emerging parasitoids, survival rate and sex ratio (percent females). These parameters are 
determined based on the method of Puspitaningtyas, Nurkomar, and Buchori (2019). We used this similar procedure to test the subject on S. litura for comparison.

\section{Statistical Analysis}

To compare the performance of T. remus on $S$. frugiperda and S. litura, all data parameters including the number of parasitized eggs, parasitism rate, number of emerging parasitoids, survival rate and sex ratio (percent females) was subjected to twopaired t-test analysis using R-statistic version 3.5.2 (RCoreTeam, 2013).

\section{RESULTS AND DISCUSSIONS}

The presence of $S$. frugiperda as a new pest in several Asian countries including Indonesia is a threat that needs attention. The presence of a new pest into a new area can cause attacks at high or low levels. An insect species can cause high attack so that it becomes the major pest in a plant, but also can be a minor pest in other plants. A pest can also be a major pest in one area but can also only be a minor pest in another area (Hill, 2008). In this case, S. frugiperda attack has threatened corn production in Africa. However, S. frugiperda attack reported has the potential to reduce corn production in Indonesia. In other words, the status of this pest is classified as a minor pest since the infestation level is still low (1 larva per plant) (Trisyono et al., 2019). Pereira and Lee Hellman (1993) concluded that the economic injury level for Spodoptera is two larva per plant in Maryland. One of the factors that cause pests to become minor pests is due to the role of natural enemies that are able to control the pest population (I Nurkomar, Manuwoto, Kainoh, $\&$ Buchori, 2018). Telenomus remus is a natural enemy that can be used as a natural enemy of some lepidopteran eggs (CABI, 2019b). Liao et al. (2019) reported $60.19 \%$ field parasitism rate of S. frugiperda by T. remus.. So far, T. remus has been reported to be used as a biological control agent of S. litura (Susiawan \& Yuliarti, 2017) and S. exigua (Buchori et al., 2017), another armyworm pest species that have long been existed in Indonesia (Kalshoven, 1981). In this study, we compare the performance of T. remus in parasiting S. frugiperda and S. litura under laboratory conditions.

The result showed that no differences in the performance of T. remus either on S. frugiperda or S. litura as host. T. remus successfully parasitized $69.40 \%$ (35/50) eggs of S. frugiperda and $80.80 \%$ (40/50) eggs of S. litura (Paired t-test, $\mathrm{P}=0.137$,

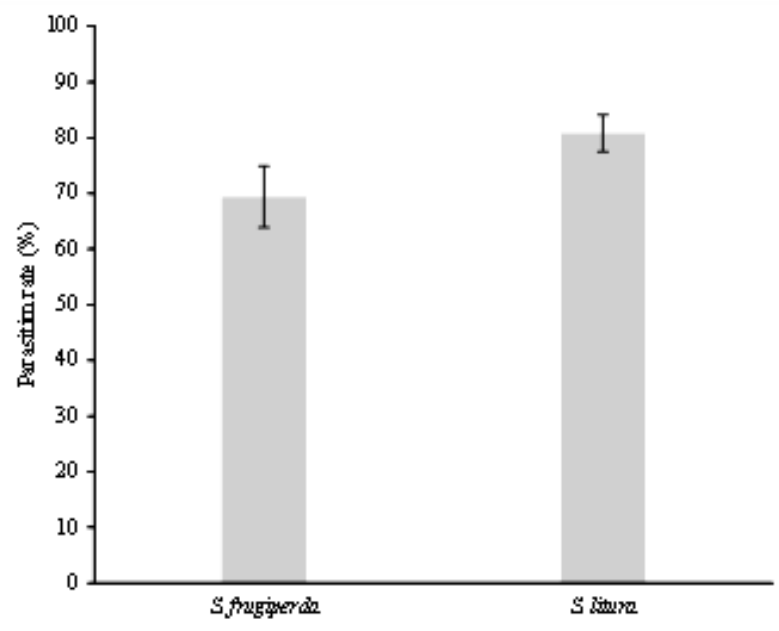

Figure 1. Parasitism rate of S. frugiperda and S. litura by Telenomus remus

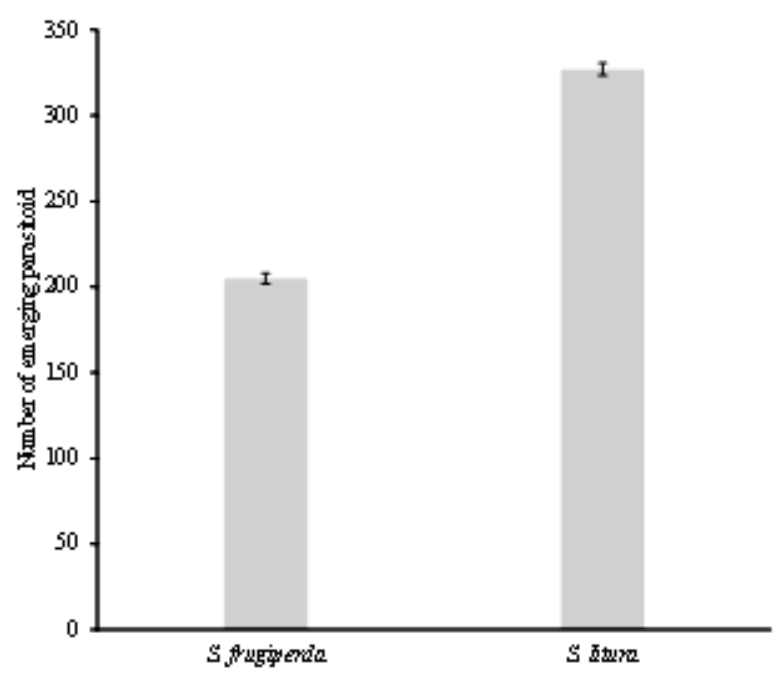

Figure 2. Number of emerging parasitoids reared on Spodoptera frugiperda and S. Litura 


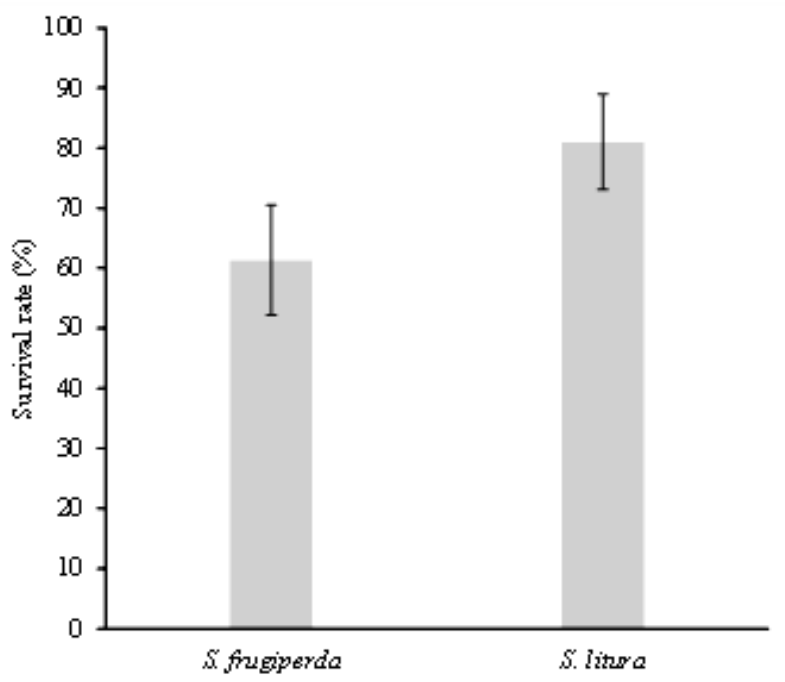

Figure 3. Survival rate of Telenomus remus reared on Spodoptera frugiperda and S. litura

$\mathrm{n}=10$ ) (Figure 1). However, there is a significant difference in the number of emerging parasitoids (Paired t-test, $\mathrm{P}=0.048, \mathrm{n}=10$ ) (Figure 2). Parasitoid produced from S. litura eggs 63\% more than those from S. frugiperda. T. remus showed high survival rate reared both of host (Paired t-test, $\mathrm{P}=0.07, \mathrm{n}=10$ ) (Figure 3). Furthermore, both of host able to produce more than $50 \%$ females (Figure 4).

The results showed that there were no differences in the performance of $T$. remus in the two hosts tested. This shows that T. remus can be used as a natural enemy for S. frugiperda (Figure 5).

Other potential natural enemies for S. frugiperda is larval parasitoid Coccygidium melleum (Hymenoptera: Braconidae), Campoletis chlorideae (Hymenoptera: Ichneumonidae), Eriborus sp. (Hymenoptera:
Ichneumonidae), Odontepyris sp. (Hymenoptera: Bethylidae), Exorista sorbillans (Diptera: Tachinidae); Forficula sp. (Dermaptera: forficulidae); predatory beetle Harmonia octomaculata (Coleoptera: Coccinellidae), Coccinella transversalis (Coleoptera: Coccinellidae), and Entomopathogenic fungi Nomuraea rileyi (Kalleshwaraswamy, Poorani, Maruthi, Pavithra, \& Diraviam, 2019).

No performance differences were shown for all parameters tested except for the number of emerging parasitoids. T. remus that is reared in S. litura produced more parasitoids than that of reared in S. frugiperda as host. This because the number of parasitized S. litura eggs is higher than the number of S. frugiperda eggs. In addition, T. remus showed no difference survival rate in both of host. Our result suggests that $T$. remus can be used as a natural enemy for controlling S. frugiperda. However, several factors need to be considered in utilizing a parasitoid as a biocontrol agent such as host selection behavior (Zuim et al., 2017). Host age must be considered for utilization of T. remus for controlling S. frugiperda since the number of S. frugiperda eggs parasitized by T. remus decreases with increasing age of the host egg (de Queiroz et al., 2019). In another study, it was also reported that the older the host age, the smaller the number of parasitized host, i.e., the number of eggs of Botesia botrana parasitized by Trichogramma cacoeciae is greater at the age of 1 or 2 days than that of 3 or 4 days old (Pizzol, Desneux, a

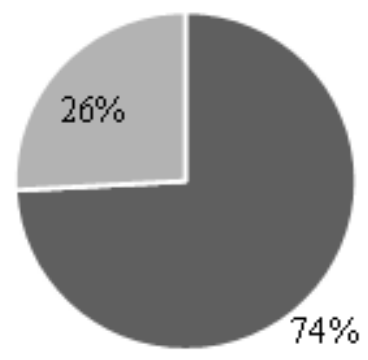

b

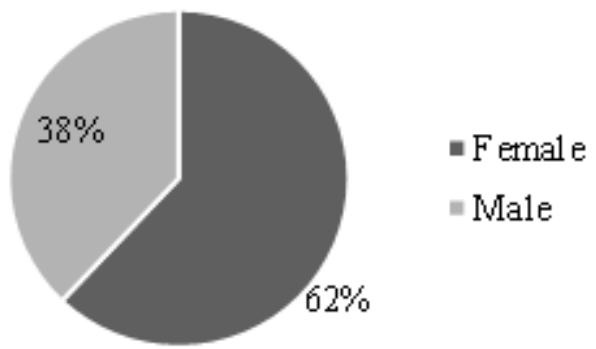

Figure 4. Sex ratio of Telenomus remus reared on S. frugiperda (a) and S. litura (b) 


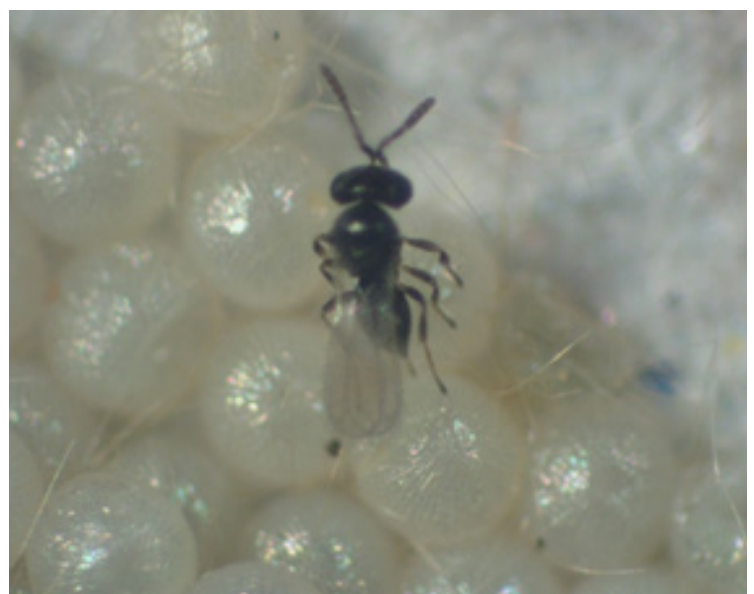

Figure 5. Telenomus remus parasitizing Spodoptera frugiperda's egg cluster

Wajnberg, \& Thiéry, 2012). However, there are also parasitoids that do not differentiate host age in the parasitization process, i.e., Trichogramma chilonis does not show differences in the level of parasitism at the different age of the host Cytotella cytella (Zahid, Farid, Sattar, \& Khan, 2007).

In this study, T. remus was exposed to 50 eggs both of S. litura and S. frugiperda. The number of parasitized eggs is 34.7 and 40.4 for S. frugiperda and S. litura respectively. This is in line with the research of (Carneiro, Fernandes, Cruz, \& Bueno, 2010) who tested the functional response of $\mathrm{S}$. frugiperda with different exposure times that on the number of host eggs by 50 eggs, the number of parasitized eggs was 20-30 eggs. In general, T. remus has a type II functional response in which the more the number of hosts is given, the number of parasitized hosts is increasing. The number of parasitic eggs does not increase at a certain host density $(150$ - 300) eggs exposed.

\section{CONCLUSION}

Our finding concluded that T. remus as a larval parasitoid of common armyworm S. litura can be used as potential biocontrol agent for controlling S. frugiperda, a new invasive pest species in several countries including Indonesia.

\section{ACKNOWLEDGEMENTS}

Authors thank to Directorate of Human Resource, IPB University and Biological Control Laboratory, Department of Plant Protection, Faculty of Agriculture, IPB University to support this research.

\section{REFERENCES}

BBPOPT. (2019). Hama invasif Spodoptera frugiperda di indonesia (Hasil verifikasi bbpopt periode April - Juni 2019). Retrieved from https://berita.bbpopt.id

Buchori, D., Herawati, E. D., \& Sari, A. (2017). The effectiveness of Telenomus remus (Nixon)(Hymenoptera: Scelionidae) for controling welsh onion pest Spodoptera exigua Hübner (Lepidoptera: Noctuidae) (in Indonesian). Jurnal Entomologi Indonesia, 5(2), 81.

CABI. (2019a). Spodoptera frugiperda (fall armyworm) Retrieved from https://www.cabi.org/isc/datasheet/53078

CABI. (2019b). Telenomus remus. Retrieved from https://www. cabi.org/isc/datasheet/53078

Carneiro, T. R., Fernandes, O. A., Cruz, l., \& Bueno, R. C. (2010). Functional response of Telenomus remus Nixon (Hymenoptera, Scelionidae) to Spodoptera frugiperda (JE Smith)(Lepidoptera, Noctuidae) eggs: effect of female age. Revista Brasileira de Entomologia, 54(4), 692-696.

Day, R., Abrahams, P., Bateman, M., Beale, T., Clottey, V., Cock, M., . .. Godwin, J. (2017). Fall armyworm: impacts and implications for Africa. Outlooks on Pest Management, 28(5), 196-201.

de Queiroz, A. P., Favetti, B. M., Luski, P. G., Gonçalves, J., Neves, P. M. 0. J., \& de Freitas Bueno, A. (2019). Telenomus remus (Hymenoptera: Platygastridae) parasitism on Spodoptera frugiperda (Lepidoptera: Noctuidae) eggs: different parasitoid and host egg ages. Semina: Ciências Agrárias, 40(6Supl2), 2933-2946.

Goergen, G., Kumar, P. L., Sankung, S. B., Togola, A., \& Tamò, M. (2016). First report of outbreaks of the fall armyworm Spodoptera frugiperda (JE Smith) (Lepidoptera, Noctuidae), a new alien invasive pest in West and Central Africa. PloS one, 11(10), e0165632.

Hill, D. (2008). Pests of crops in warmer climates and their control: Springer Science \& Business Media.

Jiang, Y., Liu, J., \& Zhu, X. (2019). Occurrence and trend of Spodoptera frugiperda invasion in China. Plant Protection, 39, 33-35.

Kalleshwaraswamy, C., Poorani, J., Maruthi, M., Pavithra, H., \& Diraviam, J. (2019). Natural enemies of Spodoptera frugiperda (JE Smith)(Lepidoptera: Noctuidae), a recent invasive pest on maize in South India. Florida Entomologist, 102(3), 619-623.

Kalshoven, L. G. E. (1981). Pests of crops in Indonesia. Jakarta: Ichtiar Baru.

Kenis, M., Du Plessis, H., Van den Berg, J., Ba, M. N., Goergen, G., Kwadjo, K. E., ... Cafà, G. (2019). Telenomus remus, a candidate parasitoid for the biological control of Spodoptera frugiperda in Africa, is already present on the continent. Insects, 10(4), 92. Liao, Y.-L., Yang, B., Xu, M.-F., Lin, W., Wang, D.-S., Chen, K.-W., \& Chen, H.-Y. (2019). First report of Telenomus remus parasit- 
izing Spodoptera frugiperda and its field parasitism in southern China. Journal of Hymenoptera Research, 73, 95-102.

Maharani, Y., Dewi, V. K., Puspasari, L. T., Rizkie, L., Hidayat, Y., \& Dono, D. (2019). Cases of fall army worm Spodoptera frugiperda JE Smith (Lepidoptera: Noctuidae) attack on maize in Bandung, Garut and Sumedang district, West Java. CROPSAVER-Journal of Plant Protection, 2(1), 38-46.

Nabity, P. D., Zangerl, A. R., Berenbaum, M. R., \& Delucia, E. H. (2011). Bioenergy crops Miscanthus giganteus and Panicum virgatum reduce growth and survivorship of Spodoptera frugiperda (Lepidoptera: Noctuidae). Journal of Economic Entomology, 104(2), 459-464.

Nurkomar, I., Manuwoto, S., Kainoh, Y., \& Buchori, D. (2018). Multitrophic Interaction between Cucumber Moth Diaphania indica Saunders,(Lepidoptera: Crambidae) and Its Natural Enemies. Paper presented at the IOP Conference Series: Earth and Environmental Science, Bogor, Indonesia.

Nurkomar, l., Puspitaningtyas, N. N., Pudjianto, Manuwoto, S., \& Buchori, D. (2017). Biology and fitness characteristics of Apanteles taragamae Viereck (Hymenoptera: Braconidae). Journal of Entomolgy, 14(3), 128-135. doi:10.3923/je.2017.128.135

Pereira, C. J., \& Lee Hellman, J. (1993). Economic injury levels for Spodoptera frugiperda (Lepidoptera: Noctuidae) on silage corn in Maryland. Journal of Economic Entomology, 86(4), 1266-1270.

Pizzol, J., Desneux, N., Wajnberg, E., \& Thiéry, D. (2012). Parasitoid and host egg ages have independent impact on various biological traits in a Trichogramma species. Journal of Pest Science, 85(4), 489-496.

Pogue, M. G. (2002). A world revision of the genus Spodoptera Guenée (Lepidoptera: Noctuidae). Memoirs of the American Entomological Society, 43, 1-201.

Puspitaningtyas, N. N., Nurkomar, I., \& Buchori, D. (2019). Biology and Reproductive Behaviour of Apanteles taragamae Viereck (Hymenoptera: Braconidae), a Larval Parasitoid of Diaphania indica Saunders (Lepidoptera: Crambidae) (in Indonesian) (in press). Jurnal Perlindungan Tumbuhan Indonesia.

RCoreTeam. (2013). A language and environment for statistical computing. Vienna: R Foundation for Statistical Computing.

Satyanarayana, J., Ballal, C., \& Rao, N. (2005). Evaluation of egg parasitoid, Telenomus remus Nixon and larval parasitoid, Campoletis chlorideae Uchida on Spodoptera litura (Fabricius) in castor. Indian Journal of Plant Protection, 33(1), 26-29.

Sparks, A. N. (1979). A review of the biology of the fall armyworm. Florida Entomologist, 62(2), 82-87.

Susiawan, E., \& Yuliarti, N. (2017). Distribution and abundance of egg parasitoids Telenomus spp. in West Sumatra: their status and potential as biological control (in Indonesian). Jurnal Entomologi Indonesia, 3(2), 104-113.

Tengkano, W., \& Suharsono, S. (2005). Ulat Grayak Spodoptera litura Fabricius (Lepidoptera: Noctuidae) pada Tanaman Kedelai dan Pengendaliannya. Buletin Palawija(10), 43-52.
Trisyono, Y. A., Suputa, S., Aryuwandari, V. E. F., Hartaman, M., \& Jumari, J. (2019). Occurrence of heavy Infestation by the fall armyworm Spodoptera frugiperda, a new alien invasive pest, in corn Lampung Indonesia. Jurnal Perlindungan Tanaman Indonesia, 23(1), 156-160.

Waage, J. K., \& Hassell, M. P. (1982). Parasitoids as biological control agents-a fundamental approach. Parasitology, 84(4), 241-268.

Zahid, M., Farid, A., Sattar, A., \& Khan, I. (2007). Effects of parasitoid and host egg age on parasitism by Trichogramma chilonis (Ishii). Journal of Science Techonology, 14(4), 381-384.

Zhang, B., Huai, L., Helen, H.-S., \& Wang, J.-J. (2011). Effect of host plants on development, fecundity and enzyme activity of Spodoptera exigua (Hübner)(Lepidoptera: Noctuidae). Agricultural Sciences in China, 10(8), 1232-1240.

Zuim, V., de Souza Rodrigues, H., Pratissoli, D., Torres, J. B., Fragoso, D. F. M., \& de Freitas Bueno, R. C. O. (2017). Age and density of eggs of Helicoverpa armigera influence on Trichogramma pretiosum parasitism. Acta Scientiarum. Biological Sciences, 39(4), 513-520. 